Article

\title{
CSR Communication Strategies of Colombian Business Groups: An Analysis of Corporate Reports
}

\author{
Jaime-Andres Correa-Garcia ${ }^{1, *}$, Maria-Antonia Garcia-Benau ${ }^{2}$ and Emma Garcia-Meca ${ }^{3}$ \\ 1 Department of Accounting, School of Economics, University of Antioquia, Calle 67 53-108 Bl., \\ Medellin 13-114, Colombia \\ 2 Department of Accounting, University of Valencia, Avenida dels Tarongers, s/n, 46022 Valencia, Spain; \\ Maria.Garcia-Benau@uv.es \\ 3 Department of Finance and Accounting, Technical University of Cartagena, Calle Real 3, 30201 Cartagena, \\ Spain; emma.garcia@upct.es \\ * Correspondence: jaime.correa@udea.edu.co; Tel.: +57-300-601-2609
}

Received: 17 April 2018; Accepted: 8 May 2018; Published: 16 May 2018

\begin{abstract}
The aim of this paper is to assess stakeholder orientation and corporate social responsibility (CSR) communication strategies in the business groups (BGs) of an emerging economy by means of content analysis. We worked with 30 non-financial BGs taken from the Colombian Stock Exchange. The study uses as its unit of analysis corporate reports that have been classified into four categories: annual reports (ARs), sustainability reports (SRs), combined reports (CRs), and integrated reports (IRs). The results show that IRs are the most similar reports, that Colombian BGs are mainly employee-oriented (ARs, SRs, CRs) and shareholder-oriented (IRs), and that response and involvement communication strategies are the most commonly used. Our research has theoretical and practical implications based on the assumption that the study of corporate reports has particular importance for those BGs with diversification strategies and international orientation, since it opens possibilities for future research.
\end{abstract}

Keywords: CSR communication strategies; business groups; Colombia; stakeholder theory; content analysis; corporate report

\section{Introduction}

Research on corporate social responsibility (CSR) communication strategies has been increasing in recent years [1-4]. The importance of the way that firms communicate their contributions to society, the environment, and development to their stakeholders is currently a relevant research topic.

An important number of the studies on communication in CSR take as their departing point the work of Morsing and Schultz [5], by positing three strategies through which firms relate to their stakeholders (such work is based on Grunig and Hunt [6]): information, response, and involvement. The first one refers to a "one-way symmetric" type of strategy, which has a disseminating nature. The other two strategies are intended to establish two-way communication and dialogue with stakeholders. These are differentiated by the response strategy, which corresponds to a "two-way asymmetric" approach where there is a basic communication flow between the company and the stakeholders. The third strategy (involvement) pertains to a "two-way symmetric" approach where greater interaction with stakeholders is sought as a mechanism of feedback and the joint construction of corporate sustainability actions.

This research centers on business groups (BGs) since they are corporate forms with differentiating characteristics [7-9], especially in emerging economies where diversification and internationalization processes dictate their agenda. An analysis of the international literature reveals that, to date, there is 
no evidence of which among the above-mentioned communication strategies BGs adopt, and which kind of stakeholder orientation they follow.

This research is conducted in Colombia, which has an emerging economy where the study of contemporary BGs is fairly recent [10]. In Colombia, BGs are on the rise, and are important for the development of the economy [11]; they have reorganized their structures in recent years in order to be more strategic [12]. Colombia is a country with a tradition of CSR practices [13] and of voluntary disclosure reporting practices [14]. Additionally, Colombian BGs are following internationalization processes [15], leading them to become 'multilatinas'; that is to say, they are firms that are located and consolidated in a Latin American country, and seek expansion and positioning in new markets [16]. Furthermore, the context of developing countries has some cultural, social, political, and economic aspects that make them different [17], and therefore interesting to study.

A recent study [18] shows that $68 \%$ of consulted investors recognize the importance of CSR reports for their investment decisions and consider the report to be the main tool for communicating CSR practices [19]. This paper aims at identifying corporate reporting practices in the BGs of an emerging economy and subsequently establishing their stakeholder orientation and prevailing CSR communication strategies. To achieve these three objectives, we applied a content analysis of 30 corporate reports from the year 2015 from BGs that are representative of the Colombian economy. Following Habek and Wolniak [20], Venturelli et al. [21], and Davila et al. [22], the BG reports under analysis were classified into four categories: annual reports (AR), sustainability reports (SR), combined reports (CR), and integrated reports (IR). We draw on the stakeholders theory [23] and previous studies [24-28] in order to define the stakeholder categories, allowing us to assess the type of orientation presented by the analyzed Colombian BGs.

This study is innovative in that it assesses BG stakeholder orientation and their CSR communication strategies by conducting a cross-corporate report analysis in an emerging country such as Colombia, and studying a type of corporate organization (group) whose relationship with CSR has not been sufficiently explored. Our results suggest that even though there is diversity in the corporate reporting of BGs, an increasing adoption of compliance with standards such as the Global Reporting Initiative (GRI) and the International Integrated Reporting Council (IIRC) is observed. The results of our study reveal that Colombian BGs are mainly oriented toward employees (AR, SR, CR) and shareholders (IR). Regarding communication strategies, our results show that the BGs employ, in a more relevant way, a "two-way" approach in their CSR communication; that is to say, they establish a strategy of fostering dialogue and joint construction.

This work has theoretical implications because it links stakeholders and CSR communication theories to those of BGs, which has not been previously explored in the literature, and thus makes this work a pioneer in this research field. Although the BG is a common organizational form for large Colombian businesses, the CSR practices, to the best of our knowledge, have not been widely studied, and we consider that Colombia represents a good example and a starting point for developing economies. At a practical level, our study provides evidence that in the area of corporate reports, there is the potential to apply improvements regarding the diversity found in the presentation of voluntary disclosure, which we consider valid for Colombia, as well as for the Latin American context. Lastly, in view of the possible future regulation of voluntary disclosure practices, this study serves as the basis for focalizing actions in that direction. Furthermore, the analysis conducted and the results obtained open the possibility for developing future lines of research.

After having introduced this work, its objectives, and opportunities for future research, the rest of the paper is organized as follows. First, we provide a theoretical context for Colombian BG and CSR practices, stakeholder theory, and CSR communication strategies. The next section explains the research design. Then, the results are presented along with their discussion. Lastly, some final considerations with conclusions, limitations, implications, and future research lines are presented. 


\section{Theoretical Framework}

BGs arise out of a need for expansion as local markets become insufficient (small) for the development of firms. Added to that, some economic, social, and political aspects encourage their corporate growth in emerging economies [9]. On the road to becoming a BG, companies usually diversify themselves in different ways through operating segments and geographic segments (international diversification), and through various forms of ownership structure (family, institutional, state) [29-31].

BGs are the main form of business in Latin America, and their listed firms represent more than $80 \%$ of the market value; in Colombia, this figure is about 60\% [32] (pp. 9, 71). BGs in Colombia have presented marked dynamics since their regulation in 1995 (Law 222 of 1995). In 2012, 2224 BGs were registered, of which only $1.1 \%$ owned 20 or more subsidiaries; $36 \%$ of the BGs were controlled by a foreign firm, and $14 \%$ of all of the subsidiaries were foreign [11]. Despite this growth, the literature evidences no studies dealing with CSR practices and SR in Colombian BG; thus, the call made by Aguilera and Crespi-Cladera [33] to study CSR in BG gains is also important in this institutional context. However, previous studies such as Gómez-Villegas and Quintanilla [34], Correa-García et al. [35] and Macias and Farfan-Lievano [36] demonstrate interest in examining voluntary disclosure practices in Colombia. Although they have not been explicitly oriented toward the issue of BGs and their particularities, some of the companies included in these papers exhibit the characteristics of BGs. These studies have mainly focused on content analysis and case studies describing CSR reporting practices, and sustainability policies implemented by the companies.

The case of Colombia is representative of emerging countries that have a great tradition of CSR practices [13]. In this sense, BGs in Colombia exert leadership, and their sustainability reports and actions are recognized, especially those groups with a greater international orientation and which meet the criterion for being multilatinas $[15,16,37]$. In sum, we could argue that Colombian BGs demonstrate a tradition of voluntary disclosure practices and specific sustainability actions. However, academia has not sufficiently addressed the way or the means through which BG communicate with their stakeholders, giving rise to opportunities of dialogue and comparison amongst scholars in the fields of CSR and BGs [10].

The rightful understanding of the concept of stakeholders is of primary importance for BGs as well as for individual companies. This concept was initially approached in the management literature in an internal memorandum made at the Stanford Research Institute in 1963 [23]. The term intended to expand the notion that shareholders were the only group that firms' management should have as users. The term stakeholders was initially defined as those groups without whose support the firm would cease to exist, which only encompassed shareholders, employees, customers, suppliers, lenders, and the community [23]. However, the stakeholders theory developed by Freeman expands the concept of interest groups that had been discussed at Stanford Research Institute in 1963, and defines it as any individual or group that can affect or be affected by the achievement of a firm's objectives [23] (p. 25). According to Jones [38], the concept of the stakeholder that was introduced by Freeman [22] formally recognizes the importance of the groups or individuals beyond the shareholders that are affected by a firm's actions.

Under the connotation of stakeholders provided by Freeman [22], these interest groups are recognized as legitimate focuses that must be attended to by firms, since they have the capacity to change a firm's direction, and the management must therefore attend to their demands in such a way that their rights are guaranteed. As pointed out by Friedman and Miles [39], stakeholders must participate, in a certain way, in decisions that substantially affect their own well-being. This postulate is in tune with the development of communication and engagement strategies that firms adopt to relate stakeholders to their CSR practices.

In order to better focalize corporate actions to the different stakeholders, some authors such as Hill and Jones [24], Clarkson [25], Donaldson and Preston [26], and Carroll and Buchholtz [27] have defined some categories to group stakeholders, suggesting that firms must focus their efforts on these 
groups in order to achieve the type of legitimacy that they are interested in, especially in relation to their communication with parties external to the companies [40]. For this reason, Manetti [41] called for more attention to be paid to the particularities of sustainability reports, and for further examination of the level of stakeholder involvement through the analysis of the disclosures made by firms.

The communication of CSR reports by firms is achieved through communication strategies. Companies that adopt sustainability practices seek to communicate them to stakeholders through appropriate channels and mechanisms. According to the seminal paper of Morsing and Schultz [5] regarding CSR communication strategies, three fundamental strategies are distinguished: information, response, and involvement. These strategies have been the object of attention in multiple CSR studies [3-5,41-44] in which the level of companies' engagement with their stakeholders is evaluated and set forth by means of the communication strategies that have been defined. These studies provide evidence of the evolution of the firms, going from one-way communication strategies (inform) to two-way communication strategies (response and involvement), which translates into corporate reports with communication actions and channels that firms have developed in order to inform the stakeholders of their interests and concerns. That is to say, they go from informing to dialoguing.

The most popular and applied communication strategy is the so-called stakeholder information strategy. It is based on a "one-way symmetric" approach whereby the firm publishes regular reports and bulletins, among others, while stakeholders appear as receptors of said reports and of their contents, in which firms' sustainability practices are included. However, even though this approach is necessary in corporate communications, it is not sufficient [5].

The stakeholder response strategy thus arises, which is based on a "two-way asymmetric" communication model [5]. Although this strategy implies a two-way communication flow, in practice it is primarily centered on giving information, rather than attending to responses [45] (p. 95). Companies placed under this approach consider CSR communication as both proactive and reactive responses [3], even though stakeholders are called to provide feedback to the firm [2].

Evolution itself brings about the third communication strategy, which is called the stakeholder involvement strategy. Habitually, companies placed under this communication strategy have surpassed the two previous approaches. This strategy supposes a phase of CSR communication process maturity. It is based on a symmetric communication model [5] and supposes establishing direct interaction with the communities [46], as well as dialogue with their stakeholders.

These strategies evidence the firms' level of commitment with CSR practices and entail great responsibility owing to the importance of communicating matters linked to sustainability. This makes the design of strategies a relevant topic in the corporations field [2,47], especially when referring to BGs, in which there is greater diversification, and in which a greater number of stakeholders are found than those in individual companies.

Hence, the communication strategies adopted by firms must advance and go from "informing" to "engaging" [3] in order to be in accordance with stakeholders' needs in an environment where communication is fast and very agile media make it dynamic, such as social media networks [48]. The first two strategies build identity, and the third one entails a social process that BGs must demonstrate in their corporate reports.

\section{Research Design}

\subsection{Sample}

For our empirical study, we worked with 30 non-financial BGs taken from the Colombian Stock Exchange (BVC, for its initials in Spanish) [49]. We chose Colombia for our study, as it is one of the founding countries of the Pacific Alliance, and a member of the Latin American Integrated Market (MILA, for its initials in Spanish). It acts in coordination with other emerging countries (Chile, Mexico, and Peru) to promote best corporate practices, besides having an integrated BG regulatory and supervisory structure [32], and having been recognized for having an important tradition in the CSR 
area [13]. Furthermore, large Colombian firms have increasingly incorporated CSR in their business strategies [50]. The BGs of our study represent $64.5 \%$ of the market value of the total number of firms available, and $94.5 \%$ of the market value of the non-financial firms. We validated they are BGs considering the Colombian legislation and the declaration in the firms' reports. We obtained the corporate reports mainly from the BGs' web pages (29 BG that represents 97\%). In the remaining cases (1 BG that represents 3\%), although the report was available on their web page (Riopaila), we obtained it by electronic mail in a format that could be edited in Nvivo. We had to discard some BGs because we could not obtain their reports in a compatible format that could be edited with the software. Table 1 presents the BG distribution and some of their attributes.

Table 1. Sample: Business Group (BG) by Region and Some Attributes.

\begin{tabular}{|c|c|c|c|c|c|c|c|c|c|c|c|}
\hline \multirow[b]{2}{*}{ Region } & \multicolumn{2}{|c|}{ Sector } & \multicolumn{3}{|c|}{ Type of Controller } & \multicolumn{2}{|c|}{$\begin{array}{c}\text { Foreign } \\
\text { Ownership }\end{array}$} & \multicolumn{2}{|c|}{ Multilatina } & \multicolumn{2}{|c|}{ Total by Region } \\
\hline & Sensitive & Non-Sensitive & Family & Institutional & State & No & Yes & No & Yes & $\begin{array}{l}\text { Absolute } \\
\text { Frequency }\end{array}$ & $\begin{array}{l}\text { Relative } \\
\text { Frequency }\end{array}$ \\
\hline Antioquia & 3 & 10 & 1 & 10 & 2 & 8 & 5 & 9 & 4 & 13 & $43.3 \%$ \\
\hline Atlantico & 0 & 1 & 0 & 1 & 0 & 1 & 0 & 1 & 0 & 1 & $3.3 \%$ \\
\hline Bogota & 3 & 10 & 0 & 9 & 4 & 6 & 7 & 11 & 2 & 13 & $43.3 \%$ \\
\hline Valle & 0 & 3 & 1 & 2 & 0 & 3 & 0 & 2 & 1 & 3 & $10.0 \%$ \\
\hline $\begin{array}{l}\text { Absolute } \\
\text { Frequency }\end{array}$ & 6 & 24 & 2 & 22 & 6 & 18 & 12 & 23 & 7 & 30 & $100.0 \%$ \\
\hline $\begin{array}{l}\text { Relative } \\
\text { Frequency }\end{array}$ & $20.0 \%$ & $80.0 \%$ & $6.7 \%$ & $73.3 \%$ & $20.0 \%$ & $60.0 \%$ & $40.0 \%$ & $76.7 \%$ & $23.3 \%$ & & \\
\hline
\end{tabular}

In the analysis by regions, it is observed that around $87 \%$ of the BGs analyzed are concentrated in Antioquia and Bogota. BGs were grouped by sensitive and non-sensitive sector following [51], taking into account that by sensitive sector we mean vulnerable industries, which are akin to environmental and social problems [52,53]. From this perspective, only $80 \%$ of the BGs are placed in sensitive industries, as previously defined. On the other hand, as the groups' diversification factor, we analyzed ownership structure, and found that the selected groups were largely controlled by institutional investors $(73.3 \%)$; the rest were controlled by the state $(20 \%)$ and families $(6.7 \%)$. Another look at ownership indicates that in $40 \%$ of the BGs, their majority shareholder was foreign, which is in accordance with the national average of $36 \%$ for Colombian BGs [11]. Lastly, it can be highlighted that seven of the BGs (23.3\%) were classified as multilatinas by the AmericaEconomia Journal [54], which provides a ranking of multilatinas that has been used in several studies $[16,22,37]$. This condition indicates that they are BGs with a greater international orientation and are thus exposed to a higher amount of stakeholders. Full details of the sample are included in Appendix A (See Table A1).

\subsection{Research Method}

The study of corporate reporting is presented as a valuable tool for understanding firms' social and communication phenomena $[4,55,56]$, so we focused our empirical study on a content analysis based on corporate reports, following previous studies in the literature [4,19,57-60]. Content analysis as a research approach allows delving deeper into CSR disclosures by BGs. We used Nvivo (specialized software for qualitative research) to obtain the input, enabling us to determine the BGs' stakeholder orientations. In this sense, the software facilitated us to obtain the word frequency by stakeholder group; this software has been previously used in works such as Hartman [61] and Hossain et al. [62]. Through the direct reading of the reports, we delimited the stakeholders that the Colombian BGs explicitly defined, and analyzed and classified their CSR strategy in order to review the elements that were inherent to their reporting such as labeling, the adoption of reporting presentation standards (e.g., IIRC, GRI, AA1000), and the maturity of the report. The reading of the reports focused mainly on sections G24 to G27 of GRI guidelines on stakeholder participation, the management (CEO/Chairperson) letter, and the section labeled "about this report" for the general aspects of the corporate report. Likewise, other distinct factors of the report and the BG, such as location, 
type of majority shareholder, and ownership structure, were considered in order to apply a univariate analysis [63].

We also calculated two disclosure indexes for each BG: one by pages, (Stakeholders Index Disclosure-SID-Pages) and the other by stakeholder group category (Stakeholders Index Disclosure-SID-Groups). The first one indicated the average number of repetitions per page, and the second indicated the average number of repetitions per stakeholder group based on the amount of categories that each BG declared. From the content analysis and based on the works of Habek and Wolniak [19], Venturelli et al. [20], and Davila et al. [21], we take the reports as basic units of analysis to then be classified in four categories. (1) An annual report (AR) includes financial information and a section devoted to sustainability topics. (2) A sustainability report (SR) is a sustainability report that is separate from the financial report. (3) A combined report (CR) includes financial information and the sustainability report in a single report. (4) An integrated report (IR) includes financial information and the sustainability report; it is also prepared under the requirements of the IIRC, and the BG makes an explicit declaration in it. To distinguish CRs from SRs, in the former, we considered those reports that included, besides CSR information, the consolidated financial statements and the notes to financial statements. In the case of Colombia, it is common that a BG additionally presents separate financial statements.

The groupings (categories) of stakeholders that were defined to assess the emphasis made by the BGs were established from reading the corporate reports and trying to identify the BGs' explicit stakeholder orientation.

Based on the BG's explicit stakeholder orientation and following the classifications presented by authors such as Freeman [23], Clarkson [25], Friedman and Miles [39], and Miles [28], we conducted Boolean searches in a similar way as Hartman et al. [61] for each stakeholder category with the aim of determining orientation in Colombian BG corporate reporting. The Boolean operator used was "OR", in such a way that different words that correspond to the same category could be grouped. The search categories were: employees, shareholders, customers, suppliers, state, and society.

Finally, two codifiers were employed to classify each BG according to its CSR communication strategy. They did their work independently, and consolidation was later performed. The assessment was carried out from the analysis of three fundamental factors: 1 . The section on stakeholder engagement in the report; 2 . BG disclosure on the communication means employed and their frequency; and 3. BG disclosure on the strategies of engagement with each stakeholder. In all the cases, verbatims were obtained, which justifies the classification provided by each codifier. The reliability of this classification is given by a Cronbach's alpha of 0.843 , which is an appropriate value according to the literature [64]. The initial level of coincidence of the codifiers was 73.3\% (22 BGs). In cases where there were differences, a discussion was held, which was helped with each codifier's support, and the reports were reviewed again until a single position was reconciled.

\section{Results and Discussion}

The results of our research include reading corporate reports to ascertain the explicit quantity of stakeholders, the maturity of the report, and its extension. Then, we present the stakeholders orientation, the evaluation of the CSR communication strategies of the business groups, and finally, a special analysis according with the multilatina attribute.

We started the analyses by reviewing the Colombian BG corporate reports in detail, considering that they constitute our unit of analysis, within the AR, SR, CR, and IR categories. With this, we obtained the necessary information to conduct the content analysis and conclude the three main objectives of this work: describe some reporting practices of the Colombian BG, determine stakeholder orientation, and provide evidence of the CSR communication strategies.

The categories that outline our stakeholders' orientation analysis were explained in the section above. These results are shown in Table 2. 
Table 2 allows to provide evidence that there is no consensus among Colombian BGs over the definition of stakeholders (amount), and therefore over the orientation of communication strategies. It is noteworthy that $73.3 \%$ of the BGs define nine or fewer orientation groups, and that there is a shared mode in the BGs that define six and seven stakeholders as their focus of CSR engagement. It is worth noticing that two BGs (Bavaria and Canacol Energy) explicitly define 17 stakeholders, while another BG (Constructora Conconcreto) does not explicitly present any stakeholder. This BG presents an annual report with a sustainability section entitled "Innovation and Sustainability". On the other hand, Alpina and Mineros are the only BGs that do not explicitly define "shareholders" as a stakeholder group [65] (pp. 9, 74) [66] (p. 19).

To meet our first objective, we assessed the BG reports, considering that the analysis of corporate reporting practices is a growing topic of current interest in Colombia and Latin America [14,34]. Colombian BGs in the year 2015 presented annual, sustainability, combined, and integrated reports. This enunciation order also obeys the level of evolution of disclosure practices at international $[67,68]$ and local [69] levels. Table 3 evidences that $6.7 \%$ of the BGs presented ARs; $63.3 \%$ of the BGs presented SRs; $16.7 \%$ of the BGs presented CRs; and $13.3 \%$ of the BGs presented IRs. This leads us to establish that 93.3\% of the BGs that we analyzed presented sustainability reporting or a superior standard, which confirms that Colombia is a country with an important tradition and application of CSR practices in Latin America. Report maturity has been used in several studies [4,21], and in our investigation, it represents the number of years that the BG has presented sustainability reports or an additional standard (SR, CR, IR).

Table 2. Quantity of Stakeholders.

\begin{tabular}{cccc}
\hline \multicolumn{4}{c}{ Explicit Stakeholders-BG } \\
\hline Quantity & Absolute Frequency & Relative Frequency & Accumulated Frequency \\
\hline 0 & 1 & $3.3 \%$ & $3.3 \%$ \\
5 & 2 & $6.7 \%$ & $10.0 \%$ \\
6 & 7 & $23.3 \%$ & $33.3 \%$ \\
7 & 7 & $23.3 \%$ & $56.7 \%$ \\
8 & 1 & $3.3 \%$ & $60.0 \%$ \\
9 & 4 & $13.3 \%$ & $73.3 \%$ \\
10 & 2 & $6.7 \%$ & $80.0 \%$ \\
11 & 2 & $6.7 \%$ & $86.7 \%$ \\
12 & 1 & $3.3 \%$ & $90.0 \%$ \\
14 & 1 & $3.3 \%$ & $93.3 \%$ \\
17 & 2 & $6.7 \%$ & $100.0 \%$ \\
\hline Total & 30 & $100.0 \%$ & \\
\hline
\end{tabular}

Table 3. Corporate Report Maturity and Extension. GRI: Global Reporting Initiative.

\begin{tabular}{|c|c|c|c|c|c|c|}
\hline & \multicolumn{6}{|c|}{ GRI Level } \\
\hline & \multicolumn{2}{|c|}{ Comprehensive } & \multicolumn{2}{|c|}{ Core } & \multicolumn{2}{|c|}{ No GRI } \\
\hline & Maturity & Pages & Maturity & Pages & Maturity & Pages \\
\hline Report Type & Mean & Mean & Mean & Mean & Mean & Mean \\
\hline $\mathrm{AR}$ & & & & & 0.0 & 184.0 \\
\hline SR & 6.5 & 134.0 & 6.4 & 113.8 & & \\
\hline CR & 6.0 & 484.5 & 3.3 & 323.7 & & \\
\hline IR & 7.0 & 309.0 & 9.0 & 385.0 & & \\
\hline
\end{tabular}

Report: AR (Annual Report), SR (Sustainability Report), CR (Combined Report), IR (Integrated Report).

Regarding maturity, those BGs with IRs presented a higher mean. This is explained because, having adopted such contemporary standards as GRI and IIRC, they have at least gone through the elaboration of AR and SR. CRs present the lowest values, because it is a type of intermediate report that is close to being an integrated report (merging financial and non-financial information), which does not meet the IIRC requirements. In both cases, maturity is independent from the level of adherence that 
the BG presented with respect to the GRI. It is clear that Conconcreto and Construcciones El Condor, which presented ARs for 2015, are not placed in the levels of adherence to the GRI. It must be noted that the BG with the greatest maturity in presenting a SR is Codensa, with 12 years, whose majority shareholder is the state. Excluding the two BGs with ARs, the BG that exhibited the least maturity in its reporting was UNE (a telecommunications company), which presented its first report in 2015, and did it directly as a CR. Its majority shareholder is also the state. "According to the GRI G4 methodology, the comparison principle does not apply, since the Company is reporting its integrated management for the first time. 2015 data act as baseline for the reports of the following years" [70] (p. 1).

Another aspect that we would like to highlight from the reports is the variety of names of corporate reports [56,71], which is natural due to the differentiation and emphasis in the message that each company seeks to convey. Although taking into account that international standards are followed, one would expect more unity in this respect. By way of example, we present the names of the BG reports found in the CR category:

- Ecopetrol: Integrated Sustainable Management Report (Reporte Integrado de Gestión Sostenible).

- $\quad$ ETB (Empresa de Telecomunicaciones de Bogotá): Management and Sustainability Report (Informe de Gestión y Sostenibilidad).

- SURA: Annual Report (Informe Anual).

- Riopaila: Sustainability and Management Report (Informe de Sostenibilidad y Gestión).

- UNE Telecomunicaciones: Management and Sustainability Report (Informe de Gestión y Sostenibilidad).

As observed in the case of ETB, UNE, and Riopaila, the name aligns perfectly with its category of "combined report". In the case of SURA, the name would place it in the AR category, although its internal structure and content is of a CR type. Lastly, in the case of Ecopetrol (Colombia's largest firm), we find ourselves in front of a "label adopter", since the name of its report leads to confusion and to thinking it is an IR, which is not true.

With the purpose of evidencing report orientation, we found that the three greatest repetitions for each report category are as follows. AR: Bancolombia, Conconcreto, and Financieros. SR: Management, Sustainability, and Report (Gestión, Sostenibilidad, Informe). CR: Value, Management, and Report (Valor, Gestión, Informe). IR: Value, Financial, and Group (Valor, Financieros, Grupo). This analysis enables us to provide evidence that Colombian BG reports meet the purpose of each type of report. In the case of ARs, their approach lies in indicating the means that this type of industry (construction) requires in order to operate, since the words allude to financing in this sector. In SRs, there is a marked orientation towards sustainability management. In CRs and IRs, the message is more directed towards value generation, which captures the evolution in the intentionality of this type of report. Furthermore, taking into account that the type of corporate report is a sign of evolution in the management and disclosure processes, it can be expected that the BG that presents a CR or IR conveys a clearer and more targeted message. This emphasis in the reports is consistent with the international orientation observed in the BGs that prepare them [72].

Finally, we conducted a conglomerate analysis through Nvivo by report category. The conglomerate analysis allows us to evaluate the level of similarity of the reports according to their textual content. In SR, Pearson correlation coefficients present a minimum of 0.914474 and a maximum of 0.9862 , which indicates a range of 0.071726 . For $C R$, the minimum value is 0.964615 , the maximum is 0.987999 , and the range is 0.023384 . IR evidence a minimum coefficient of 0.985697 , a maximum of 0.995419 , and a range of 0.009722. Lastly, in AR, and keeping in mind that we only had two BG under this category, we found a correlation coefficient of 0.864467 . This analysis reveals that as Colombian BGs evolve in corporate reporting practices toward the integrated report, the similarity and orientation in language coincides more with other firms, which is explained by the maturity of the report and the internationalization and diversification characteristics adopted by the BG. Regarding ARs, the analysis also indicates that there is much lower similarity in this than in the other report categories, because ARs do not follow a specific standard. 
The second objective that we pursued seeks to determine the stakeholder orientation of Colombian BGs (see Tables 4 and 5), and shows the total number of repetitions for each stakeholder group. Our cross-corporate report analysis indicates that employees are the stakeholders toward whom the BGs are most oriented, with $29.2 \%$ of the total of the repetitions in the reports. This suggests that the sustainability strategies of the BGs consider employees as a preponderant group, which is evidenced by the fact that in $53.3 \%$ (16) of the BGs, they were the stakeholders with the most repetitions in the report. Nevertheless, for the BGs that presented IRs, shareholders was the most representative category, with $24.2 \%$ of the repetitions, although closely followed by employees (24.1\%), which aligns with IR purposes of focusing on value creation over time [73,74].

It can be observed from our analysis that the general stakeholder orientation order is given as follows: (1) employees, (2) shareholders, (3) society, (4) customers, (5) suppliers, and (6) state. Notably, the state stakeholder is quite distant from the general orientation. The BGs that are most oriented toward this stakeholder group are Ecopetrol and ISA, which have the state as their majority shareholder, and Grupo Argos, which participates in highly regulated activities such as construction and energy. These three BGs share the characteristic of belonging to sensitive sectors.

As additional analysis, we apply an ANOVA. First, we validated the variance homogeneity test, and through the Levene statistic, we found significance for the employees, customers, and suppliers dimensions $(0.548,0.192$, and 0.414 , respectively). Then, the ANOVA analysis shows significant evidence of $0.027,0.085$, and 0.109 , respectively. For the above, with a level of confidence of $5 \%$, we can indicate that there is a difference between the means of the types of reports and the group employees. For shareholders, state, and society, we apply the nonparametric test of Kruskal-Wallis and find a chi-square value of 19,974 and significance of 0.000 for shareholders, and a chi-square value of 16,078 and a significance of 0.001 for state. With this, we can claim that there are differences in the means between the types of reports and these two stakeholder groups. For the society group, we cannot make this claim.

In the case of SID-Pages, the SR category presented the greatest number of repetitions per page (3.831), and the AR category presented the lowest (1.533). On the other hand, when we reviewed the SID-Groups, we found that the IR category presented the greatest number of average repetitions for stakeholders (127.675), closely followed by the CR category (121.43). This indicates that these two report categories (CR and IR) place greater emphasis on their message to stakeholders, and the differences between BGs presenting ARs and SRs are noticeable.

CSR communication strategies determine to a great extent the level of involvement with their stakeholders [5]. With this analysis, we meet our third central objective. In this sense, our cross-corporate report analysis detailed in Table 6 indicates that $50 \%$ of the BGs that were analyzed are placed in the "Response" strategy, and $43.3 \%$ are placed in the "Involvement" strategy, which implies that only two of the BGs (6.7\%) were classified in the "Information" strategy (Conconcreto and Colombina). Conconcreto presents an AR, because the report's innovation and sustainability section does not express communication strategies or materiality assessment. In the case of Colombina, the report does not state in detail how the group communicates with and relates to stakeholders. Table 7 presents some examples that support the classification conducted by the codifiers.

With respect to the determination of the communication strategy, we reviewed the disclosures on the channels and methods used by the BG in a similar way as Manetti [41], identifying a great diversity of means, but highlighting the use of web pages, electronic bulletins by stakeholder group, quarterly reports, transparency telephone lines, shareholder meetings, and regular meetings with some groups, especially suppliers, customers, and community members. The majority of BGs ( $24 \%$ to $80 \%$ ) enunciates the specific means and channels for communication with each stakeholder group; the others do this in a general way. 
Table 4. Stakeholder orientation. SID: Stakeholders Index Disclosure.

\begin{tabular}{|c|c|c|c|c|c|c|c|c|c|c|c|c|}
\hline \multicolumn{13}{|c|}{ Number of Mentions } \\
\hline Report Type & BG & Pages Average & Q Stakeholders (Average) & Employees & Shareholders & Customers & Suppliers & State & Society & Total Stakeholders & SID Pages & SID Groups \\
\hline AR & 2 & 184 & 3.50 & 183 & 110 & 88 & 56 & 15 & 81 & 533 & 1.533 & 14.714 \\
\hline SR & 19 & 116 & 9.00 & 2557 & 652 & 1344 & 1483 & 410 & 1454 & 7900 & 3.831 & 53.139 \\
\hline $\mathrm{CR}$ & 5 & 388 & 7.25 & 1391 & 1279 & 658 & 616 & 415 & 707 & 5066 & 2.646 & 121.143 \\
\hline IR & 4 & 366 & 8.74 & 871 & 872 & 622 & 423 & 309 & 511 & 3608 & 2.567 & 127.675 \\
\hline Total & 30 & 199 & 8.23 & 5002 & 2913 & 2712 & 2578 & 1149 & 2753 & 17107 & 3.311 & 73.819 \\
\hline
\end{tabular}

Report: AR (Annual Report), SR (Sustainability Report), CR (Combined Report), IR (Integrated Report). 
Table 5. Average by Stakeholder Category.

\begin{tabular}{cccccccccc}
\hline Report Type & BG & Pages & Employees & Shareholders & Customers & Suppliers & State & Society & Total \\
\hline AR & 2 & 184 & 0.343 & 0.206 & 0.165 & 0.105 & 0.028 & 0.152 & 1.00 \\
CR & 5 & 388 & 0.275 & 0.252 & 0.130 & 0.122 & 0.082 & 0.140 & 1.00 \\
IR & 4 & 366 & 0.241 & 0.242 & 0.172 & 0.117 & 0.086 & 0.142 & 1.00 \\
SR & 19 & 116 & 0.324 & 0.083 & 0.170 & 0.188 & 0.052 & 0.184 & 1.00 \\
Total & 30 & & 0.292 & 0.170 & 0.159 & 0.151 & 0.067 & 0.161 & 1.000 \\
\hline
\end{tabular}

Report: AR (Annual Report), SR (Sustainability Report), CR (Combined Report), IR (Integrated Report).

Table 6. Communication Strategies.

\begin{tabular}{ccccccc}
\hline Strategy & AR & SR & CR & IR & Absolute Frequency & Relative Frequency \\
\hline Information & 1 & 1 & 0 & 0 & 2 & 0.067 \\
Response & 1 & 12 & 2 & 0 & 15 & 0.500 \\
Involvement & 0 & 6 & 3 & 4 & 13 & 0.433 \\
\hline Absolute Frequency & 2 & 19 & 5 & 4 & 30 & 1.000 \\
\hline Relative Frequency & 0.067 & 0.633 & 0.167 & 0.133 & 1.000 & \\
\hline \multicolumn{2}{r}{ Report: AR (Annual Report), SR (Sustainability Report), CR (Combined Report), IR (Integrated Report). }
\end{tabular}

Table 7. Selected Examples describes Communication Strategies.

\begin{tabular}{|c|c|}
\hline Strategy & Representative Statements \\
\hline Information & $\begin{array}{l}\text { For this reason, we made the decision to start incorporating } \\
\text { a sustainability approach in the Management Report this year, } \\
\text { with the Global Reporting Initiative (GRI-G4*) methodology as } \\
\text { a guide, advancing towards a better understanding of the Company's } \\
\text { stakeholders and creating our first materiality analysis with the } \\
\text { accompaniment of consulting experts in the field [75] (p. 6). }\end{array}$ \\
\hline Response & $\begin{array}{l}\text { In these pages, we report the means and frequency with which we } \\
\text { communicate with our shareholders by type of group. Throughout the } \\
\text { year, we permanently approach and communicate with each stakeholder } \\
\text { group, through different means and with different frequency [76] (p. 72). } \\
\text { For our Business Group, permanent engagement with stakeholders is of } \\
\text { special consideration, whether through direct consultation as we did in } \\
\text { the } 2014 \text { report, which will be carried out again in 2016, or through } \\
\text { activities by the Corporate Communications Division [66] (p. 11). }\end{array}$ \\
\hline Involvement & $\begin{array}{l}\text { At Grupo Familia }{ }^{\circledR} \text { we are committed to building trust relationships } \\
\text { with the groups we relate to, so that we can maintain constant } \\
\text { communication and contact with them, generating shared value. With } \\
\text { the aim of developing engagement strategies fit to the reality of each } \\
\text { one of them, we have defined a series of two-way communication } \\
\text { channels [77] (p. 17). } \\
\text { Annually, we invite our stakeholders to participate in the Dialogues for } \\
\text { Sustainability, a space framed in the promotion of sustainability, with } \\
\text { the purpose of sharing with them the most relevant information about } \\
\text { our social responsibility performance and fostering a space for joint } \\
\text { reflection, enabling us to have a broad and balanced vision for } \\
\text { decision-making [78] (p. 42). }\end{array}$ \\
\hline
\end{tabular}


We found that the BGs that were placed in the "two-way" type strategies hold meetings usually called "Dialogues with Stakeholders" which, according to Hess [70] and Venturelli et al. [20], is an element that places a company in this strategy. Nonetheless, the BGs that were classified as having an "Involvement" strategy gave more participation to stakeholders and considered them in the construction of their report. The Colombian BGs highlight the corporate report as the most important means of relating with stakeholders, since it is a transversal means of communication that shows sustainability management in an integrated way. Another aspect to highlight is that only $27 \%$ of the BGs presented social networks as an explicit means of communication with stakeholders, which appears as a channel to exploit by the BGs, since works such as Kollat and Farache [1] report on the relevance of social networks.

All of the BGs that included SR, CR, or IR presented the materiality matrix, which is a requirement from the GRI. This matrix supposes the assessments of the most relevant themes for stakeholders; however, although its construction takes stakeholders into account, this participation pertains to a "two-way asymmetric" response approach, since this is carried out primarily by means of surveys, interviews, and analysis of specialized studies, in line with what has been proposed by Hess [79] and Moratis and Brandt [4]. Meanwhile, the BGs that were placed under a "two-way symmetric" communication approach developed a set of activities where the participation of stakeholders was more active and taken into account in the construction of not only the materiality matrix, but also in the construction of the report and the sustainability strategy (e.g., "In Grupo SURA, we are aware of the importance of relating with our stakeholders in a strategic manner, under the frame of our corporate objectives, considering the needs and expectations of the different parties and with a long-term perspective") [80] (p. 74).

We could determine a significant association between the CSR communication strategy and the type of corporate report presented by the Colombian BGs (chi-square $=13.804$ and ${ }^{* *} p=0.034$ ). This indicates that the strategy can be determined from the type of report presented by the BGs, since the BGs that were closer to the concept of an IR reported greater and better engagement with their stakeholders (two-way symmetric), whereas the few groups that still presented ARs were closer to a "one-way" symmetric strategy, because they had not fully incorporated the GRI guidelines in their sustainability management model. The next and last review we performed consisted of classifying corporate reports and sustainability strategies according to the multilatina nature of the BGs analyzed (Table 8). The reason for this is, as can be observed in previous works on Latin American BGs [7,81], that BG internationalization is one of the factors measuring their degree of diversification. Additionally, multilatinas have emerged as a study field, not only from internalization and corporate strategy phenomena, but also from finances, corporate governance, and sustainability, among others.

Table 8. BG Multilatinas and Corporate Social Responsibility (CSR) Communication Strategies.

\begin{tabular}{cccccccc}
\hline & \multicolumn{3}{c}{ Corporate Report } & \multicolumn{3}{c}{ Strategies } \\
\hline Multilatina & AR & SR & CR & IR & Information & Response & Involvement \\
\hline Yes & 0.000 & 0.100 & 0.033 & 0.100 & 0.033 & 0.433 & 0.300 \\
No & 0.067 & 0.533 & 0.133 & 0.033 & 0.033 & 0.067 & 0.133 \\
\hline
\end{tabular}

Report: AR (Annual Report), SR (Sustainability Report), CR (Combined Report), IR (Integrated Report).

As shown in Table 8, being a multilatina implies, in terms of reports, developing at least sustainability reports independently and two-way communication strategies. We placed Colombina in the "Information" strategy only because its SR did not account for the communication channels and specific strategies developed with stakeholders. Its only declaration in this sense is: "Our strategic objective departs from the creation of long-term value for our Stakeholders. That is why in Colombina we have mechanisms enabling us to establish risk and attenuate impacts, in order to have sustainable relationships with each stakeholder group" [82] (p. 6). 
With all the analyses performed, we could provide evidence that, although on the road to diversification and internationalization, Colombian BGs did not observe homogenous corporate reporting practices. However, some of them (13.3\%) have already adopted best practices through presenting IRs; and another important segment (16.7\%) is approaching this standard through presenting CRs. Conglomerate analyses show that there is not great dissimilarity by type of report, notwithstanding the differences regarding the extension and maturity of the report. This leads us to think, and according with studies on CSR conducted for Colombia, that the tradition of their companies in presenting non-voluntary reports drives a process of permanent referencing among firms. Regarding stakeholder orientation, the Colombian BGs center primarily on employees. This may be because Colombia has been objected to constant revisions by multinational organizations on the protections of workers' rights [32,50], so BGs seek to attend to the demands of this stakeholder group adequately. With reference to CSR communication strategies, we can speak of a certain maturity, since $93.3 \%$ of the BGs are oriented toward "two-way" strategies.

\section{Concluding Remarks}

In this study, we have focused on making a contribution to the literature by providing evidence on reporting, stakeholder orientation, and CSR communication strategy practices among Colombian BGs. These three elements are essential for understanding the way in which an emerging economy such as Colombia approaches reporting, and the way that it wishes to establish a relationship with its stakeholders.

The Colombian case is very interesting, because in the last 20 years, the country has been working on adjusting legislation related to BG in order to facilitate business development [32], and because there has existed a political and stock market integration with Chile, Mexico, and Peru in the Pacific Alliance and the MILA. This favorable environment has motivated the consolidation and expansion of Colombian BGs, through which some of them have become multilatinas, which is an additional factor that was considered in our investigation. The BGs displaying such conditions mostly developed communication strategies of permanent dialogue with their stakeholders.

By analyzing reporting practices through a content analysis approach, the empirical results pointed at annual reports (ARs) as the only means of corporate report that appeared as a minority practice, since only $6.7 \%$ of the BGs followed this model. On the contrary, $93.3 \%$ of the BGs prepared a sustainability report (SR), and an increasing number of them (four) is incorporating the integrated report (IR) as best practice in corporate reporting. Our analysis points out that there are important differences among reports in their labeling, orientation, extension, and maturity. However, these differences are smaller in the IR category, where the calculated range based on Pearson correlation coefficients was the lowest for the report categories. The particularities found in the analysis of the reports lead us to conclude that the study of corporate reporting practices is an issue of current interest that incites the interests of BGs, scholars, and regulatory entities.

The stakeholder orientation that we addressed here is a topic of interest in CSR literature [57] that has not been explored for BGs. Considering that diversified BGs attend to different operating and geographic segments, it is relevant to determine the degree of stakeholder orientation and asses that the emphasis that they frame is affected by the corporate or institutional factors where they operate. In our case, we found that Colombian BGs orient their corporate reports primarily toward employees (AR, SR, CR) and shareholders (IR), denoting that the report captures stakeholder perception and needs mainly when there are communication strategies promoting constructive dialogue. 
Colombian BGs mainly employ CSR communication strategies where dialogue with stakeholders is determinant (two-way). Nevertheless, our study showed that there is still an important segment of BG that must advance on these strategies in order to achieve greater levels of engagement and establish communication channels and means that are adequate to the different stakeholder categories. Our content analysis through reading direct reports enabled us to establish that not all BGs are sufficiently clear in expressing their mechanisms of engagement with stakeholders. Thus, we conclude that the construction of the materiality matrix does not suppose the development of an involvement strategy per se, in the same sense as set forth by previous works from Hess [79] and Moratis and Brandt [4].

This work has some limitations. One of them is that it deals with only one country. However, previous works $[57,83]$ have conducted content analysis for a single country. Also, Colombia stands out as a leading country in Latin America in what relates to actions of follow-up and control to BGs, as well as voluntary disclosure practices, which makes it an important study case. Basing our research on reports and not contrasting them with interviews, surveys, or experiments [56] can affect the criteria for classifying the communication strategies; however, the mechanism employed to carry out this assessment yielded a significant reliability level. On the other hand, upon centering on the corporate report as a unit of analysis to conduct this study, we left aside media such as web pages and social networks, which are currently a source of relevant studies on CSR communication practices [1].

This work has two main implications: for academics, because to the best of our knowledge, it is one the first papers to study the CSR-BG relationship, especially in relation to CSR communication strategies; and for practitioners, because we could see that BG corporate reporting practices signify an important challenge and need to be improved. The Colombian context extends the debate about CSR communication strategies, because it is a representative developing economy of Latin American and its BGs are in the process of internationalization, with many of them becoming multilatinas. This study encourages future research to continue the study presented in this paper by conducting investigations on BGs centering on social networks as strategic tools to relate to stakeholders and engage them in CSR practices. However, we consider that such work should be linked with report analysis, because with some stakeholder categories, the report continues to be the only means of CSR communication.

Author Contributions: The manuscript was written through join contributions from all authors. The three authors participated in designing the article, defining the theme and methodology and writing the paper. In this study J.-A.C.-G. obtained the data-source of the Colombian business groups, and M.-A.G.-B. and E.G.-M. revised the final version of the paper. All authors have given approval to the final version of the manuscript.

Acknowledgments: The authors acknowledge the financial support from the Generalitat Valenciana AICO/2017/092 and the financial support of the Spanish Ministry of Economy, Industry and Competitiveness (Project ECO 2017-82259-R).

Conflicts of Interest: The authors declare no conflict of interest. 


\section{Appendix}

Table A1. Colombian Business Groups: Attributes and CSR Communication Strategies.

\begin{tabular}{|c|c|c|c|c|c|c|c|c|c|c|c|c|}
\hline Code & $\begin{array}{c}\text { Colombian } \\
\text { Business Group }\end{array}$ & Report & Region & GRI Level & $\begin{array}{l}\text { Majority } \\
\text { Shareholder }\end{array}$ & $\begin{array}{c}\text { Foreign } \\
\text { Ownership }\end{array}$ & Controller Type & Multilatina & Strategies & Maturity & Pages & $\begin{array}{l}\text { Number of } \\
\text { Stakeholders }\end{array}$ \\
\hline 1 & Cementos Argos & IR & Antioquia & Core & $61.00 \%$ & 0 & Institutional & 1 & 3 & 9 & 296 & 7 \\
\hline 2 & Grupo Argos & IR & Antioquia & Core & $35.60 \%$ & 0 & Financial & 1 & 3 & 9 & 442 & 9 \\
\hline 3 & Grupo Nutresa & IR & Antioquia & Comprehensive & $35.70 \%$ & 0 & Financial & 1 & 3 & 7 & 309 & 7 \\
\hline 4 & ISA & IR & Antioquia & Core & $51.41 \%$ & 0 & State & 1 & 3 & 9 & 417 & 6 \\
\hline 5 & Ecopertrol & $\mathrm{CR}$ & Bogotá & Comprehensive & $88.49 \%$ & 0 & State & 1 & 3 & 7 & 676 & 7 \\
\hline 6 & ETB & $C R$ & Bogotá & Core & $86.58 \%$ & 0 & State & 0 & 3 & 7 & 303 & 10 \\
\hline 7 & Grupo SURA & $C R$ & Antioquia & Comprehensive & $23.81 \%$ & 0 & Institutional & 1 & 3 & 5 & 293 & 9 \\
\hline 8 & Riopaila & $\mathrm{CR}$ & Valle & Core & $5.77 \%$ & 0 & Institutional & 0 & 2 & 2 & 374 & 8 \\
\hline 9 & UNE & $\mathrm{CR}$ & Antioquia & Core & $50.01 \%$ & 0 & State & 0 & 2 & 1 & 294 & 11 \\
\hline 10 & Conconcreto & $\mathrm{AR}$ & Antioquia & No GRI & $20.00 \%$ & 1 & Institutional & 0 & 1 & 0 & 306 & 0 \\
\hline 11 & El Condor & $\mathrm{AR}$ & Antioquia & No GRI & $26.00 \%$ & 0 & Familiar & 0 & 2 & 0 & 62 & 7 \\
\hline 12 & Alpina & SR & Bogotá & Core & $16.96 \%$ & 1 & Financial & 0 & 2 & 7 & 84 & 6 \\
\hline 13 & Avianca & SR & Bogotá & Core & $51.53 \%$ & 1 & Institutional & 1 & 2 & 7 & 148 & 6 \\
\hline 14 & Bavaria & SR & Bogotá & Comprehensive & $94.86 \%$ & 1 & Institutional & 0 & 3 & 9 & 164 & 17 \\
\hline 15 & Canacol & SR & Bogotá & Core & $23.13 \%$ & 1 & Financial & 0 & 2 & 2 & 78 & 17 \\
\hline 16 & Caracol & SR & Bogotá & Core & $93.50 \%$ & 0 & Institutional & 0 & 3 & 6 & 164 & 10 \\
\hline 17 & Cemex LATAM & SR & Bogotá & Core & $93.90 \%$ & 1 & Institutional & 1 & 3 & 5 & 81 & 14 \\
\hline 18 & Codensa & SR & Bogotá & Core & $51.50 \%$ & 0 & State & 0 & 3 & 12 & 192 & 9 \\
\hline 19 & Colombina & SR & Valle & Core & $15.76 \%$ & 0 & Family & 1 & 1 & 7 & 52 & 6 \\
\hline 20 & EEB & SR & Bogotá & Core & $76.28 \%$ & 0 & State & 0 & 3 & 7 & 256 & 7 \\
\hline 21 & Enka & SR & Antioquia & Core & $16.50 \%$ & 0 & Financial & 0 & 2 & 3 & 54 & 6 \\
\hline 22 & Éxito & SR & Antioquia & Core & $41.40 \%$ & 1 & Institutional & 1 & 2 & 8 & 97 & 6 \\
\hline 23 & Gas Natural & SR & Bogotá & Core & $59.10 \%$ & 1 & Institutional & 0 & 2 & 11 & 76 & 5 \\
\hline 24 & Grupo Orbis & SR & Antioquia & Core & $15.12 \%$ & 1 & Financial & 0 & 2 & 5 & 75 & 6 \\
\hline 25 & Mayaguez & SR & Valle & Core & $67.46 \%$ & 0 & Financial & 0 & 3 & 6 & 122 & 5 \\
\hline 26 & Mineros & SR & Antioquia & Core & $17.70 \%$ & 1 & Financial & 0 & 2 & 8 & 136 & 7 \\
\hline 27 & Organización Terpel & SR & Bogotá & Core & $56.18 \%$ & 1 & Institutional & 0 & 2 & 7 & 148 & 12 \\
\hline 28 & Productos Familia & SR & Antioquia & Core & $26.34 \%$ & 1 & Institutional & 0 & 3 & 3 & 72 & 11 \\
\hline 29 & Promigas & SR & Atlántico & Core & $34.22 \%$ & 0 & Financial & 0 & 2 & 5 & 100 & 7 \\
\hline 30 & $\mathrm{RCN}$ & SR & Bogotá & Comprehensive & $39.42 \%$ & 0 & Institutional & 0 & 2 & 4 & 104 & 9 \\
\hline
\end{tabular}

Report: AR (Annual Report), SR (Sustainability Report), CR (Combined Report), IR (Integrated Report); Foreign Ownership: 1: Majority shareholder is foreign, 0: Otherwise. Multilatina: 1: BG is a Multilatina included in the America Economia Ranking, 0: Otherwise. Strategies: 1: Information strategy, 2: Response strategy, 3: Involve 


\section{References}

1. Kollat, J.; Farache, F. Achieving consumer trust on Twitter via CSR communication. J. Consum. Mark. 2017, 34, 505-514. [CrossRef]

2. Walter, B.L. Corporate Social Responsibility Communication: Towards a Phase Model of Strategic Planning. In Communicating Corporate Social Responsibility: Perspectives and Practice; Emerald Group Publishing Limited: Bingley, UK, 2014; Volume 6, pp. 59-79.

3. Lim, J.S.; Greenwood, C.A. Communicating corporate social responsibility (CSR): Stakeholder responsiveness and engagement strategy to achieve CSR goals. Public Relat. Rev. 2017, 43, 768-776. [CrossRef]

4. Moratis, L.; Brandt, S. Corporate stakeholder responsiveness? Exploring the state and quality of GRI-based stakeholder engagement disclosures of European firms. Corp. Soc. Responsib. Environ. Manag. 2017, 24, 312-325. [CrossRef]

5. Morsing, M.; Schultz, M. Corporate social responsibility communication: Stakeholder information, response and involvement strategies. Bus. Ethics Eur. Rev. 2006, 15, 323-338. [CrossRef]

6. Grunig, J.E.; Hunt, T. Managing Public Relations; 1984; ISBN 0030583373. Available online: https: / / www.abebooks.co.uk/servlet/BookDetailsPL?bi=22832421136\&searchurl=tn\%3Dmanaging\%

2Bpublic\%2Brelations\%26sortby\%3D17\%26an\%3Djames\%2Bgrunig\%2Btodd\%2Bhunt\&cm_sp=snippet-_srp1-_title1 (accessed on 17 April 2018).

7. Borda, A.; Geleilate, J.M.G.; Newburry, W.; Kundu, S.K. Firm internationalization, business group diversification and firm performance: The case of Latin American firms. J. Bus. Res. 2017, 72, 104-113. [CrossRef]

8. Khanna, T.; Yafeh, Y. Business Groups and Risk Sharing around the World. J. Bus. 2005, 78, 301-340. [CrossRef]

9. Guillén, M.F. Business Groups in Emerging Economies: A Resource-Based View. Acad. Manag. J. 2000, 43, 362-380.

10. Dávila, C.; Dávila, J.C. The Evolution of a Socially Committed Business Group in Colombia, 1911-85. Aust. Econ. Hist. Rev. 2014, 54, 164-182. [CrossRef]

11. Superintendencia de Sociedades. Comportamiento de los Grupos Empresariales del Sector Real de la Economía. 2012. Available online: https:/ / www.google.com/url?sa=t\&rct=j\&q=\&esrc=s\&source=web\&cd=1\& ved=0ahUKEwjr74uWnYnbAhWLJpQKHY1wD7QQFggnMAA\&url=https\%3A\%2F\%2Fwww.supersociedades. gov.co\%2Fdelegatura_aec\%2Festudios_financieros\%2FDocuments\%2FSector\%2520Real\%2520Economia\%2F2\% 2520Informe\%2520Conglo\%25202012.pdf\&usg=AOvVaw2pUqVZT3EOohfJnwybsyBy (accessed on 17 April 2018).

12. Wilches-Sánchez, G.; Rodríguez-Romero, C.A. El proceso evolutivo de los Conglomerados o Grupos Económicos en Colombia. Innovar. Rev. Ciencias Adm. y Soc. 2016, 26, 11-33. [CrossRef]

13. Acosta, P.; Pérezts, M. Unearthing Sedimentation Dynamics in Political CSR: The Case of Colombia. J. Bus. Ethics 2017, 1-20. [CrossRef]

14. Del Mar Alonso-Almeida, M.; Marimon, F.; Llach, J. Difusión de las memorias de sostenibilidad en Latinoamérica: Análisis territorial y sectorial. Estud. Gerenciales 2015, 31, 139-149. [CrossRef]

15. Gonzalez-Perez, M.A.; Velez-Ocampo, J.F. Targeting one's own region: Internationalisation trends of Colombian multinational companies. Eur. Bus. Rev. 2014, 26, 531-551. [CrossRef]

16. Cuervo-Cazurra, A. The multinationalization of developing country MNEs: The case of multilatinas. J. Int. Manag. 2008, 14, 138-154. [CrossRef]

17. Ali, W.; Alsayegh, M.F.; Ahmad, Z.; Mahmood, Z.; Iqbal, J. The relationship between social visibility and CSR disclosure. Sustainability 2018, 10, 866. [CrossRef]

18. Ernst \& Young. Is Your Nonfinancial Performance Revealing the True Value of Your Business to Investors? 2017. Available online: https:/ / www.google.com/url?sa=t\&rct=j\&q=\&esrc=s\&source=web\&cd=1\&cad=rja\& uact=8\&ved=0ahUKEwj2xJLfn4nbAhVBp5QKHXBYDyAQFggnMAA\&url=http $\% 3 \mathrm{~A} \% 2 \mathrm{~F} \% 2 \mathrm{Fwww} \cdot$ ey.com $\%$ 2FPublication\%2FvwLUAssets\%2FEY_-_Nonfinancial_performance_may_influence_investors\%2F\%24FILE\% 2Fey-nonfinancial-performance-may-influence-investors.pdf\&usg=AOvVaw1Hjd2wh2M2bQyjM1qm6EXz (accessed on 17 April 2018).

19. Lock, I.; Seele, P. The credibility of CSR (corporate social responsibility) reports in Europe. Evidence from a quantitative content analysis in 11 countries. J. Clean. Prod. 2015, 122, 186-200. [CrossRef] 
20. Habek, P.; Wolniak, R. Assessing the quality of corporate social responsibility reports: The case of reporting practices in selected European Union member states. Qual. Quant. 2016, 50, 399-420. [CrossRef] [PubMed]

21. Venturelli, A.; Cosma, S.; Leopizzi, R. Stakeholder Engagement: An Evaluation of European Banks. Corp. Soc. Responsib. Environ. Manag. 2018. [CrossRef]

22. Davila, A.; Rodriguez-Lluesma, C.; Elvira, M.M. Engaging Stakeholders in Emerging Economies: The Case of Multilatinas. J. Bus. Ethics 2018. [CrossRef]

23. Freeman, R.E. Strategic Management: A Stakeholder Approach; Pitman Publishing Inc.: Boston, MA, USA, 1984; Volume 1, ISBN 0631218602.

24. Hill, C.W.L.; Jones, T.M. Stakeholder-Agency Theory. J. Manag. Sutd. 1992, 29, 131-154. [CrossRef]

25. Clarkson, M.B.E. A Stakeholder Framework for Analyzing and Evaluating Corporate Social Performance. Acad. Manag. Rev. 1995, 20, 92-117. [CrossRef]

26. Donaldson, T.; Preston, L.E. The Stakeholder Theory of the Corporation: Concepts, Evidence, and Implications. Acad. Manag. Rev. 1995, 20, 65-91. [CrossRef]

27. Carroll, A.B.; Buchholtz, A.K. Business and Society-Ethics and Stakeholder Management; Nelson Education Limited: Toronto, ON, Canada, 2008; ISBN 9780324569391.

28. Miles, S. Stakeholder Theory Classification: A Theoretical and Empirical Evaluation of Definitions. J. Bus. Ethics 2017, 142, 437-459. [CrossRef]

29. Carney, M.; Gedaylovic, E.R.; Huegens, P.P.M.A.; Van Essen, M.; Van Oosterhout, J. Business group affiliation, performance, context, and strategy: A meta-analysis. Acad. Manag. J. 2011, 54, 437-460. [CrossRef]

30. Barbero, M.I.; Puig, N. Business groups around the world: An introduction. Bus. Hist. 2016, 58, 6-29. [CrossRef]

31. Khanna, T.; Yafeh, Y. Business Groups in Emerging Markets: Paragons or Parasites? J. Econ. Lit. 2007, 45, 331-372. [CrossRef]

32. OECD. Corporate Governance of Company Groups in Latin America; OECD Publishing: Paris, France, 2015; ISBN 9789264240124.

33. Aguilera, R.V.; Crespi-Cladera, R. Global corporate governance: On the relevance of firms' ownership structure. J. World Bus. 2016, 51, 50-57. [CrossRef]

34. Gómez-Villegas, M.; Quintanilla, D.A. Los informes de responsabilidad social empresarial: Su evolución y tendencias en el contexto internacional y colombiano. Cuad. Contab. 2012, 13, 121-158.

35. Correa-García, J.A.; Hernández-Espinal, M.C.; Vásquez-Arango, L.; Soto-Restrepo, Y.M. Reportes integrados y generación de valor en empresas colombianas incluidas en el Índice de Sostenibilidad Dow Jones. Cuad. Contab. 2016, 17, 73-108. [CrossRef]

36. Macias, H.A.; Farfan-Lievano, A. Integrated reporting as a strategy for firm growth: Multiple case study in Colombia. Meditari Account. Res. 2017, 25, 605-628. [CrossRef]

37. Aguilera, R.V.; Ciravegna, L.; Cuervo-Cazurra, A.; Gonzalez-Perez, M.A. Multilatinas and the internationalization of Latin American firms. J. World Bus. 2017, 52, 447-460. [CrossRef]

38. Jones, T.M. Instrumental Stakeholder Theory: A Synthesis of Ethics and Economics. Acad. Manag. Rev. 1995, 20, 404-437. [CrossRef]

39. Friedman, A.L.; Miles, S. Stakeholders Theory and Practice; Oxford University Press: New York, NY, USA, 2006; ISBN 9780199269877.

40. Bebbington, J.; Larrinaga, C.; Moneva, J.M. Corporate social reporting and reputation risk management. Account. Audit. Account. J. 2008, 21, 337-361. [CrossRef]

41. Manetti, G. The quality of stakeholder engagement in sustainability reporting: Empirical evidence and critical points. Corp. Soc. Responsib. Environ. 2011, 18, 110-122. [CrossRef]

42. Morsing, M. Strategic CSR communication: Telling others how good you are. Manag. Model. Corp. Soc. Responsib. 2006, 238-246. [CrossRef]

43. Morsing, M.; Schultz, M.; Nielsen, K.U. The "Catch 22" of communicating CSR: Findings from a Danish study. J. Mark. Commun. 2008, 14, 97-111. [CrossRef]

44. Koep, L. Tensions in aspirational CSR communication-A longitudinal investigation of CSR reporting. Sustainability 2017, 9, 2202. [CrossRef]

45. Bekmeier-Feuerhahn, S.; Bögel, P.M.; Koch, C. Investigating Internal CSR Communication: Building a Theoretical Framework. In Handbook of Integrated CSR Communication; Springer International Publishing AG: Gewerbestrasse, Switzerland, 2017; pp. 89-107. ISBN 978-3-319-44698-1. 
46. Dhanesh, G.S. The Paradox of Communicating CSR in India: Minimalist and Strategic Approaches. J. Public Relat. Res. 2015, 27, 431-451. [CrossRef]

47. Bruhn, M.; Zimmermann, A. Integrated CSR Communications. In Handbook of Integrated CSR Communication; Springer International Publishing AG: Gewerbestrasse, Switzerland, 2017; pp. 3-21. ISBN 978-3-319-44698-1.

48. Saxton, G.D.; Waters, R.D. What do Stakeholders Like on Facebook? Examining Public Reactions to Nonprofit Organizations' Informational, Promotional, and Community-Building Messages. J. Public Relat. Res. 2014, 26, 280-299. [CrossRef]

49. BVC, Bolsa Valores de Colombia. Available online: https://www.bvc.com.co/pps/tibco/portalbvc/Home/ Empresas/Listado+de+Emisores (accessed on 23 March 2017).

50. Jansen, H.; Veeneman, P. CSR in Colombia. Observations and Recommendations; Edward Elgar Publishing Limited: Cheltenham, UK, 2016.

51. Van de Burgwal, D.; Vieira, R.J.O. Environmental disclosure determinants in Dutch listed companies. Rev. Contab. Finanç. 2014, 25, 60-78.

52. Zorio-Grima, A.; García-Benau, M.A.; Sierra-García, L. Aseguramiento del informe de sostenibilidad en España y Latinoamérica. Innovar. Rev. Ciencias Adm. y Soc. 2015, 85-102. [CrossRef]

53. Sierra-García, L.; García-Benau, M.A.; Zorio-Grima, A. Credibilidad en Latinoamérica del informe de responsabilidad social corporativa. Rev. Adm. Empres. 2014, 54, 28-38. [CrossRef]

54. AmericaEconomia. Ranking Multilatinas. 2015. Available online: https://boliviaemprende.com/ publicaciones/americaeconomia-presenta-ranking-multilatinas-2015 (accessed on 17 April 2018).

55. Guthrie, J.; Petty, R.; Yongvanich, K.; Ricceri, F. Using Content Analysis as a Research Method to Inquire into Intellectual Capital Reporting; 2004; Volume 5, ISBN 1469-1930. Available online: https: / www.emeraldinsight. com/doi/abs/10.1108/14691930410533704 (accessed on 17 April 2018).

56. Hahn, R.; Kühnen, M. Determinants of sustainability reporting: A review of results, trends, theory, and opportunities in an expanding field of research. J. Clean. Prod. 2013, 59, 5-21. [CrossRef]

57. Jain, T.; Aguilera, R.V.; Jamali, D. Corporate Stakeholder Orientation in an Emerging Country Context: A Longitudinal Cross Industry Analysis. J. Bus. Ethics 2017, 143, 701-719. [CrossRef]

58. Campopiano, G.; De Massis, A. Corporate Social Responsibility Reporting: A Content Analysis in Family and Non-family Firms. J. Bus. Ethics 2015, 129, 511-534. [CrossRef]

59. Liao, P.C.; Xia, N.N.; Wu, C.L.; Zhang, X.L.; Yeh, J.L. Communicating the corporate social responsibility (CSR) of international contractors: Content analysis of CSR reporting. J. Clean. Prod. 2017, 156, 327-336. [CrossRef]

60. Tarquinio, L. An Investigation of Global Reporting Initiative Performance Indicators in Corporate Sustainability Reports: Greek, Italian and Spanish Evidence. Sustainability 2018, 10, 897. [CrossRef]

61. Hartman, L.P.; Rubin, R.S.; Dhanda, K.K. The communication of corporate social responsibility: United States and European Union multinational corporations. J. Bus. Ethics 2007, 74, 373-389. [CrossRef]

62. Hossain, M.; Islam, T.; Ahmed, M.; Shamsun, M.; Samsul, N. Understanding Communication of Sustainability Reporting: Application of Symbolic Convergence Theory (SCT). J. Bus. Ethics 2018. [CrossRef]

63. Block, J.H.; Stiglbauer, M.; Kühn, A.-L.; Wagner, D. Corporate social responsibility communication of German family firms: A content analysis. Umwelt WirtschaftsForum 2015, 23, 251-257. [CrossRef]

64. Eberle, D.; Berens, G.; Li, T. The Impact of Interactive Corporate Social Responsibility Communication on Corporate Reputation. J. Bus. Ethics 2013, 118, 731-746. [CrossRef]

65. Alpina Reporte de Sostenibilidad 2015; Alpina: Cundinamarca, Colombia, 2015.

66. Grupo-Mineros Memoria de Sostenibilidad 2015; Mineros S.A.: Medellín, Antioquia, Colombia, 2015.

67. Shabana, K.M.; Buchholtz, A.K.; Carroll, A.B. The Institutionalization of Corporate Social Responsibility Reporting. Bus. Soc. 2016, 1-29. [CrossRef]

68. Rivera-Arrubla, Y.A.; Zorio-Grima, A.; García-Benau, M.A. El concepto de informe integrado como innovación en reporting corporativo. J. Innov. Knowl. 2016, 1, 144-155. [CrossRef]

69. Correa-Garcia, J.A.; Pulgarín Arias, A.F.; Muñoz Osorio, L.M.; Álvarez Osorio, M.C. Marco normativo y antecedentes de la revelación contable en Colombia. Contaduría Univ. Antioquia 2010, 269-292.

70. UNE-Telecomunicaciones Informe de Gestión y Sostenibilidad 2015; UNE-Telecomunicaciones: Medellín, Colombia, 2015.

71. Demirbag, M.; Wood, G.; Makhmadshoev, D.; Rymkevich, O. Varieties of CSR: Institutions and Socially Responsible Behaviour. Int. Bus. Rev. 2017, 26, 1064-1074. [CrossRef] 
72. Yin, J.; Jamali, D. Strategic Corporate Social Responsibility of Multinational Companies Subsidiaries in Emerging Markets: Evidence from China. Long Range Plan. 2016, 49, 541-558. [CrossRef]

73. Stacchezzini, R.; Melloni, G.; Lai, A. Sustainability management and reporting: The role of integrated reporting for communicating corporate sustainability management. J. Clean. Prod. 2016, 136, 102-110. [CrossRef]

74. Adams, C.A.; Potter, B.; Singh, P.J.; York, J. Exploring the implications of integrated reporting for social investment (disclosures). Br. Account. Rev. 2016, 48, 283-296. [CrossRef]

75. Contrucciones-El-Condor Informe Anual de Gestión y Estados Financieros 2015; Construcciones el Condor S.A.: Medellín, Colombia, 2015.

76. Grupo-Exito Informe de Sostenibilidad 2015; Grupo-Éxito: Medellín, Colombia, 2015.

77. Grupo-Familia Informe de Sostenibilidad 2015; Grupo-Familia: Medellín, Colombia, 2015.

78. Cementos-Argos Reporte Integrado 2015; Cementos-Argos: Medellín, Colombia, 2015.

79. Hess, D. The three pillars of corporate social reporting as new governance regulation: Disclosure, dialogue, and development. Bus. Ethics Q. 2008, 18, 447-482. [CrossRef]

80. Grupo-SURA Informe Anual 2015; Grupo-SURA: Medellín, Colombia, 2015.

81. Castellacci, F. Group Affiliation and Firms' Export Intensity: A Cross-Country Study. Rev. Econ. Inst. 2015, 6, 1-22. [CrossRef]

82. Grupo-Empresarial-Colombina Informe de Sostenibilidad 2015; Colombina: Valle del Cauca, Colombia, 2015.

83. Tang, L.; Li, H. Corporate social responsibility communication of Chinese and global corporations in China. Public Relat. Rev. 2009, 35, 199-212. [CrossRef]

(c) 2018 by the authors. Licensee MDPI, Basel, Switzerland. This article is an open access article distributed under the terms and conditions of the Creative Commons Attribution (CC BY) license (http://creativecommons.org/licenses/by/4.0/). 